\title{
PERTUMBUHAN DAN PRODUKSI VARIETAS SELADA (Lactuca sativa L) PADA BERBAGAI DOSIS PUPUK ORGANIK RUMPUT LAUT
}

\author{
S. Z. Abidin ${ }^{a}$, Oktavianus ${ }^{b}$, dan S. A. Adimihardja ${ }^{b}$ \\ ${ }^{a}$ Mahasiswa S1 Jurusan Agroteknologi, Fakultas Pertanian, Universitas Djuanda Bogor \\ b Staf Pengajar Jurusan Agroteknologi, Fakultas Pertanian, Universitas Djuanda Bogor
}

\begin{abstract}
Abstrak
Selada (Lactuca sativa) termasuk kelompok tanaman sayuran daun yang dikenal dimasyarakat. Jenis sayuran ini mengandung zat-zat gizi khususnya vitamin dan mineral yang lengkap untuk memenuhi kebutuhan gizi masyarakat. Penelitian ini bertujuan untuk mengetahui pengaruh pemberian pupuk organik rumput laut terhadap pertumbuhan dan produksi Selada (Lactuca sativa L.). Penelitian ini dilakukan pada bulan April - Maret 2014 dan bertempat di lahan penelitian dan laboratorium Budidaya Pertanian, Jurusan Agroteknologi, Fakultas Pertanian, Universitas Djuanda Bogor. Penelitian ini disusun menggunakan rancangan acak lengkap (RAL), dua faktor yaitu dua varietas selada $(\mathrm{V})$ dengan menggunakan pupuk organik rumput laut $(\mathrm{R})$. Pupuk organik rumput laut (R) terdiri dari lima taraf, yaitu R0 tanpa pupuk, R1 $500 \mathrm{~kg} / \mathrm{ha}(0,5$ rekomendasi), R2 1000 $\mathrm{kg} / \mathrm{ha}$ (1 rekomendasi), R3 $1500 \mathrm{~kg} / \mathrm{ha}$ (1,5 rekomendasi), R4 $2000 \mathrm{~kg} / \mathrm{ha}$ (2 rekomendasi). Varietas selada terdiri dari dua varietas, yaitu yang pertama selada kriting V1 (Lactuca sativa var. New grand rapid.), kedua selada merah V2 (Lactuca sativa var. new red fire).
\end{abstract}

Kata kunci : Varietas selada, pupuk organik rumput laut, pertumbuhan dan Produksi.

\section{Abstract}

Lettuce (Lactuca sativa L.) is a widely known leave vegetable. This vegetable is so rich in nutrient contents particularly vitamins and minerals that people can consume it to meet their nutrient requirements. This study was aimed at assessing the effects of sea grass organic fertilizer administration on the growth and production of lettuce. The study was conducted at the trial farm of Department of Agrotechnology, Faculty of Agriculture, Djuanda University, Bogor from March to April 2014. A completely randomized design with two factors consisting of lettuce variety (V) and sea grass organic fertilizer (R) was used. The varieties of lettuce consisted of curly lettuce (Lactuca sativa var. New grand rapid) (V1) and red lettuce (Lactuca sativa var. new red fire) (V2). Sea grass organic fertilizer (R) was given in three levels, namely no fertilizer (R0), 500 $\mathrm{kg} / \mathrm{ha}(0.5$ recommended rate) $(\mathrm{R} 1), 1000 \mathrm{~kg} / \mathrm{ha}(1.0$ recommended rate) $(\mathrm{R} 2), 1500 \mathrm{~kg} / \mathrm{ha}(1.5$ recommended rate) $(\mathrm{R} 3)$, and $2000 \mathrm{~kg} / \mathrm{ha}$ (2.0 recommended rate) (R4).

Keywords: lettuce variety, sea grass organic fertilizer, growth and production.

\section{PENDAHULUAN}

\section{Latarbelakang}

Selada (Lactuca sativa) termasuk kelompok tanaman sayuran daun yang dikenal dimasyarakat. Jenis sayuran ini mengandung zat-zat gizi khususnya vitamin dan mineral yang lengkap untuk memenuhi kebutuhan gizi masyarakat. Selada juga sebagai bahan makanan bisa dikonsumsi dalam bentuk segar sebagai lalapan yang dimakan bersama dengan bahan makanan lain. (Wicaksono, 2008).

Cahyono (2005) menyatakan bahwa selada mempunyai nilai ekonomi yang tinggi setelah kubis krop, kubis bunga dan brokoli. Selama ini umumnya budidaya selada 
dilakukan secara konvensional menggunakan masukan berbahan kimia. Namun seiring dengan meningkatnya kesadaran kesehatan masyarakat maka dikembangkanlah budidaya secara organik. Dalam budidaya selada secara organik tidak digunakan bahan kimia baik pupuk berupa pestisida.

Selama ini pemupukan selada biasanya menggunakan pupuk buatan sehingga mempunyai kekurangan dan kelebihannya (BPTP Jambi 2009). Keunggulan pupuk anorganik adalah hasilnya cepat terlihat pada tanaman, kandungan unsur hara jelas, mudah pengaplikasiannya, tidak bau dan pengangkutan mudah sedangkan kekurangan pupuk anorganik adalah mengakibatkan residu pada tanah, penggunaannya dapat merusak tanah, harga mahal dan bersifat higroskop (Nanang 2013). Menurut Notohadinegoro (2006) pertanian organik merupakan sistem pertanian yang bertujuan untuk tetap menjaga keselarasan (harmoni) dengan sistem alami dengan memanfaatkan dan mengembangkan semaksimal mungkin proses-proses alami dalam pengelolaan usaha tani, sehingga adanya pertanian organik akan lebih menjaga ekosistem pertanian, kesuburan tanah dan keanekaragaman hayati.

Alternatif pupuk yang digunakan adalah pupuk alami seperti pupuk rumput laut. Basmal (2012) dari Balai Besar Riset Pengolahan dan Bioteknologi Kelautan dan Perikanan dalam satu uraian menyatakan keistimewaan rumput laut sebagai pupuk organik adalah kekayaan kandungan zat pengatur tumbuh (ZPT)-nya. ZPT tidak hanya dapat meningkatkan produksi, tetapi juga meningkatkan daya tahan tanaman terhadap kekeringan dan serangan serangga, serta memperbaiki struktur tanah. Rumput laut diketahui mengandung banyak hara mikro besi, boron, kalsium, tembaga, khlor, kalium, magnesium, posfor, sulfur, seng dan mangan. Selain itu juga mengandung ZPT seperti auksin, sitokinin, giberilin, asam abisat dan etilen.

\section{Tujuan}

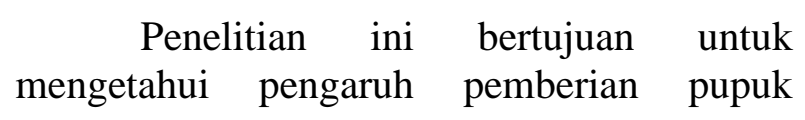

organik rumput laut terhadap pertumbuhan dan produksi Selada (Lactuca sativa L.).

\section{Hipotesis}

1. Terdapat satu dosis pupuk organik rumput laut yang dapat meningkatkan pertumbuhan dan produksi Selada (Lactuca sativa L.).

2. Terdapat satu varietas Selada (Lactuca sativa L.) yang mempunyai pertumbuhan dan produksi yang tinggi.

3. Terdapat interaksi antara pupuk organik rumput laut dengan varietas selada terhadap pertumbuhan dan produksi selada (Lactuca sativa $\mathrm{L}$.

\section{BAHAN DAN METODE PENELITIAN}

Tempat Dan Waktu Penelitian

Penelitian ini dilakukan pada bulan Februari - Maret 2014 dan bertempat di lahan penelitian dan laboratorium Budidaya Pertanian, Jurusan Agroteknologi, Fakultas Pertanian, Universitas Djuanda Bogor.

\section{Bahan Dan Alat Penelitian}

Bahan yang digunakan pada penelitian adalah benih tanaman selada, pupuk rumput laut sebanyak 500-1000kg/ha (Rukmana 2008), polibeg berukuran $5 \mathrm{~kg}$, pupuk kompos, pupuk kandang kambing.

Alat yang digunakan pada penelitian ini antara lain cangkul, polibag, plastik, meteran, timbangan analitik, handsprayer, , kamera, kalkulator, oven, alat tulis, dan hand refraktometer.

\section{Rancangan Penelitian}

Penelitian ini disusun menggunakan rancangan acak lengkap (RAL), dua faktor yaitu dua varietas selada (V) dengan menggunakan pupuk organik rumput laut $(\mathrm{R})$

Pupuk organik rumput laut $(\mathrm{R})$ terdiri dari lima taraf, yaitu tanpa pupuk organik rumput laut (R0), pupuk organik rumput laut $500 \mathrm{~kg} / \mathrm{ha}(0,5$ rekomendasi) (R1), pupuk organik rumput laut $1000 \mathrm{~kg} / \mathrm{ha}$ (1 rekomendasi) (R2), pupuk organik rumput laut $1500 \mathrm{~kg} / \mathrm{ha}$ (1,5 rekomendasi) (R3), pupuk organik rumput laut $2000 \mathrm{~kg} / \mathrm{ha}$ (2 
rekomendasi) (R4). Varietas selada terdiri dari dua varietas, yaitu yang pertama selada kriting (Lactuca sativa var. New grand rapid.) (V1), kedua selada merah (Lactuca sativa var. new red fire) (V2). Dengan demikian dalam penelitian ini terdapat 10 kombinasi perlakuan, setiap perlakuan diulang 3 kali dengan 3 tanaman setiap perlakuan sehingga tanaman yang digunakan dalam penelitian ini sebanyak 90 tanaman.

Model matematika dari rancangan acak lengkap faktorial sebagai berikut:

$$
Y_{i j k}=\mu+V_{i}+R_{j}+(V R)_{i j}+€_{i j}
$$

\section{Pelaksanaan Penelitian}

\section{Pembuatan Media Tanam}

Media tanam yang digunakan berupa tanah yang berasal dari kebun percobaan Jurusan Agroteknologi Fakultas Ilmu dan Bisnis Pangan Universitas Djuanda Bogor dari lapisan top soil pada kedalaman 0-30 cm. Tanah tersebut di keringkan dalam greenhous selama satu minggu dan disaring dengan ayakan berdiameter $0,5 \mathrm{~cm}$ sehingga diperoleh tanah yang homogen. Masingmasing polybag diisi tanah kering sebanyak 8 $\mathrm{kg}$ tanah/polybag.

\section{Penanaman}

Sebelum dipindah kedalam polybag, benih selada disemai terlebih dahulu dalam bak penyemaian. Benih disebarkan dalam bak penyemaian kemudian dilakukan pemeliharaan sampai tumbuh dan menghasilkan 2 helai daun. Jarak antar polybag $25 \times 25 \mathrm{~cm}$.

\section{Pemeliharaan}

Pemeliharaan tanaman meliputi kegiatan penyiraman, penyiangan, pemupukan dan pengendalian hama penyakit. Penyiraman disesuaikan dengan kondisi iklim. Penyiangan dilakukan setiap minggu selama penelitian.

\section{Panen}

Pemanenan selada dilakukan 40-50 hari setelah tanam, dilakukan sebelum kemunculan bunga dan dilakukan secara serempak.

\section{Peubah yang Diamati}

\section{a. Pertumbuhan dan Produksi}

1. Tinggi tanaman, diukur dari pangkal batang samapi ke titik tumbuh. Diamati setiap minggu, mulai umur 2 MST (minggu setelah tanam) sampai 5 MST

2. Jumlah daun, dihitung semua daun yang telah terbuka sempurna setiap minggu, mulai dari umur 2 MST sampai 4 MST

3. Panjang tajuk, diukur saat panen, pengukuran dimulai dari pangkal batang sampai ketitik tumbuh

4. Panjang akar, diukur saat panen, pengukuran dimulai dari leher akar sampai ujung akar terpanjang

5. Rata-rata total luas daun, 3 helai daun (satu daun atas, satu daun tengah dan satu daun bawah) lalu dikalikan dengan jumlah daun. Pengukurannya sendiri menggunakan menggunakan metode gravimetric (perbandingan berat).

\section{Bobot Kertas Replika x Luas Kertas Standar Bobot Kertas Standar}

6. Bobot basah, dilukukan pada saat panen, dengan menimbang seluruh bagian tanaman

7. Bobot kering (biomas), dilukukan setelah seluruh bagian tanaman dioven dengan suhu $100{ }^{\circ} \mathrm{C}$ selama 18 jam

8. Berat tajuk, dilakukan saat panen, dengan menimbang dari pangkal batang sampai ketiik tumbuh

9. Berat akar, dilakukan saat panen, dengan menimbang dari leher akar sampai ujung akar

\section{b. Biokimia}

\section{Padatan Terlarut Total (PTT),} dilakukan saat panen dengan menggunakan alat Hand Refraktometer (ATAGO 9102)

\section{HASIL DAN PEMBAHASAN}

\section{Keadaan Umum}

Tanah yang digunakan pada penelitian ini berjenis latosol dengan $\mathrm{pH}$ berkisar 5,16,0. Hari hujan selama penelitian ini 8 hari/bulan dengan rata-rata $3-4$ jam/hari 
dengan jenis hujan normal dan hujan deras/ekstrim.

Benih selada yang digunakan Lactuca sativa var. New grand rapid dan Lactuca sativa var. new red fire, penyakit yang menyerang selama penelitian adalah busuk daun dikarenakan cuaca yang hujan terus yang mengakibatkan daun menyentuh tanah sehingga terkena air berlebihan menyebabkan busuk pada daun.

\section{Tinggi Tanaman}

Hasil sidik ragam ( Lampiran 1 ) menunjukkan bahwa tinggi tanaman pada umur 2 MST sampai 5 MST tidak dipengaruhi oleh V (varietas), tetapi dipengaruhi oleh perlakuan $\mathrm{R}$ (pupuk organik rumput laut). Pada umur 4 MST, tanaman selada yang diberi perlakuan R1 (7,72 b), R2 (7,82 b), R3 $(7,49 \mathrm{ab})$ dan $\mathrm{R} 4(8,14 \mathrm{~b})$ lebih tinggi dibandingkan dengan yang tidak diberi perlakuan R0 $(6,74 a)$ dan pada umur 5 MST, tanaman selada yang diberi perlakuan R1 (9,53 b), R2 (9,62 b), R3 (9,66 b) dan R4 (9,93 b) lebih tinggi dibandingkan dengan yang tidak diberi perlakuan R0 (8,10 a) (Tabel 2)

Tabel 2 Tinggi tanaman selada hasil uji lanjut DMRT 5\% umur 2-5 MST

\begin{tabular}{lcccc}
\hline \multirow{2}{*}{ Pelakuan } & \multicolumn{4}{c}{ Tinggi tanaman $(\mathrm{cm})$} \\
\cline { 2 - 5 } Varietas & 2MST & 3MST & 4MST & 5MST \\
\hline V1 new grand rapid & 4,18 & 6,01 & 7,53 & 9,15 \\
V2 new red fire & 4,23 & 6,02 & 7,63 & 9,59 \\
\hline Pupuk & 4,05 & 5,40 & $6,74 \mathrm{a}$ & $8,10 \mathrm{a}$ \\
R0 0 ton/ha & 4,03 & 5,90 & $7,72 \mathrm{~b}$ & $9,53 \mathrm{~b}$ \\
R1 500 ton/ha & 4,30 & 6,26 & $7,82 \mathrm{~b}$ & $9,62 \mathrm{~b}$ \\
R2 1000 ton/ha & 4,29 & 6,09 & $7,49 \mathrm{ab}$ & $9,66 \mathrm{~b}$ \\
R3 1500 ton/ha & 4,34 & 6,43 & $8,14 \mathrm{~b}$ & $9,93 \mathrm{~b}$ \\
R4 2000 ton/ha & &
\end{tabular}

Keterangan : Nilai rata-rata pada kolom yang sama diikuti huruf yang sama tidak berbeda nyata menurut uji DMRT pada taraf F 0,05

\section{Jumlah Daun}

Hasil sidik ragam (Lampiran 2) menunjukkan bahwa jumlah daun yang dipengaruhi oleh varietas adalah pada umur 2 MST dan 4 MST, sedangkang yang dipengaruhi oleh pupuk organik rumput laut hamya pada umur 4MST. Dari sidik ragam ini tidak adanya interaksi antara $\mathrm{V}$ dan $\mathrm{R}$ (Tabel 3).

Tabel 3 Jumlah daun tanaman selada hasil uji lanjut DMRT 5\% umur 2-5 MST

\begin{tabular}{lcccc}
\hline \multirow{2}{*}{ Pelakuan } & \multicolumn{4}{c}{ Jumlah daun (helai) } \\
\cline { 2 - 5 } & 2MST & 3MST & 4MST & 5MST \\
\hline Varietas & & & & \\
V1 new grand rapid & $2,36 \mathrm{a}$ & $3,04 \mathrm{a}$ & $3,53 \mathrm{a}$ & 4,76 \\
V2 new red fire & $2,77 \mathrm{~b}$ & $3,29 \mathrm{~b}$ & $3,80 \mathrm{~b}$ & 4,91 \\
\hline Pupuk & & & & \\
R0 0 ton/ha & 2,58 & 2,94 & $3,17 \mathrm{a}$ & $3,83 \mathrm{a}$ \\
R1 500 ton/ha & 2,56 & 3,11 & $3,67 \mathrm{bc}$ & $4,83 \mathrm{~b}$ \\
R2 1000 ton/ha & 2,44 & 3,06 & $3,44 \mathrm{ab}$ & $4,94 \mathrm{bc}$ \\
R3 1500 ton/ha & 2,56 & 3,44 & $3,83 \mathrm{c}$ & $5,05 \mathrm{bc}$ \\
R4 2000 ton/ha & 2,67 & 3,28 & $4,22 \mathrm{~d}$ & $5,50 \mathrm{c}$ \\
\hline
\end{tabular}

Keterangan : Nilai rata-rata pada kolom yang sama diikuti huruf yang sama tidak berbeda nyata menurut uji DMRT pada taraf F 0,05 


\section{Luas Daun}

Hasil sidik ragam (Lampiran 3) ratarata luas daun tanaman selada dipengaruhi oleh varietas dan pupuk organik rumput laut, seperti dalam (Tabel 4) menunjukan V1 $\left(3,88^{*}\right)$ berbeda nyata dengan V2 $(1,87)$ dan perlakuan R4 $\left(3,37^{*}\right)$ sangat berbeda nyata dengan perlakuan R0 $(2,66)$

Tabel 4 Rata-rata luas daun tanaman selada

\begin{tabular}{lc}
\hline & Luas daun $(\mathrm{cm})$ \\
\hline \multicolumn{1}{c}{ Varietas } \\
V1 new grand rapid & $3,88^{*}$ \\
V2 new red fire & 1,87 \\
\hline Pupuk & \\
R0 0 ton/ha & 2,66 \\
R1 500 ton/ha & 3,00 \\
R2 1000 ton/ha & 2,17 \\
R3 1500 ton/ha & 3,19 \\
R4 2000 ton/ha & $3,37^{*}$ \\
\hline
\end{tabular}

Keterangan : Nilai rata-rata pada kolom yang sama diikuti tanda * berbeda nyata pada taraf $\mathrm{F} 0,05$

\section{Bobot Basah Total dan Bobot Kering Total Tanaman}

Hasil sidik ragam (Lampiran 4) bobot basah total tanaman selada dipengaruhi oleh varietas dan pupuk organik rumput laut tidak berpengaruh, seperti dalam (Tabel 5) menunjukan V1 $\left(15,38^{*}\right)$ berbeda nyata dengan V2 $(8,49)$.

Tabel 5 Rata-rata bobot basah total tanaman selada

\begin{tabular}{lc}
\hline & Bobot basah $(\mathrm{g})$ \\
\hline \multicolumn{1}{c}{ Varietas } & \\
V1 new grand rapid & $15,38^{*}$ \\
V2 new red fire & 8,49 \\
\hline \multicolumn{1}{c}{ Pupuk } & \\
R0 0 ton/ha & 13,78 \\
R1 500 ton/ha & 11,61 \\
R2 1000 ton/ha & 10,5 \\
R3 1500 ton/ha & 13,25 \\
R4 2000 ton/ha & 15,89 \\
\hline
\end{tabular}

Keterangan : Nilai rata-rata pada kolom yang sama diikuti tanda $*$ berbeda nyata pada taraf F 0,05

Hasil sidik ragam (Lampiran 4) bobot basah total tanaman selada juga menunjukan adanya interaksi yang nyata antara $\mathrm{V}$ dan $\mathrm{R}$, seperti dalam (Tabel 6) perlakuan R0V1 (10,11 ab), R1V1 (15,22 ab), R3V1 (16,67 b) dan R4V1 (25,56 c) sangat berbeda nyata dengan perlakuan R2V1 (9,33 ab), sedangkan perlakuan R0V2 (9,67 ab), R1V2 (8 ab), R2V2 (8,72 ab) dan R3V2 (9,83 ab) sangat berbeda nyata dengan perlakuan R4V2 $(6,22$ a).

Tabel 6 Hasil uji lanjut DMRT 5\% bobot basah total tanaman selada

\begin{tabular}{lcr}
\hline \multirow{2}{*}{ PERLAKUAN } & \multicolumn{2}{c}{ Bobot basah $(\mathrm{g})$} \\
\cline { 2 - 3 } R0 0 ton/ha & $10,11 \mathrm{ab}$ & $\mathrm{V} 2$ \\
$\mathrm{R} 1500$ ton/ha & $15,22 \mathrm{ab}$ & $9,67 \mathrm{ab}$ \\
R2 1000 ton/ha & $9,33 \mathrm{ab}$ & $8,72 \mathrm{ab}$ \\
R3 1500 ton/ha & $16,67 \mathrm{~b}$ & $9,83 \mathrm{ab}$ \\
R4 2000 ton/ha & $25,56 \mathrm{c}$ & $6,22 \mathrm{a}$ \\
\hline Keterangan : Nilai rata-rata pada kolom yang sama \\
\multicolumn{3}{c}{ diikuti huruf yang sama berbeda nyata } \\
\multicolumn{3}{c}{ menurut uji DMRT taraf 5\% }
\end{tabular}

Hasil sidik raagam (Lampiran 5) menunjukan bobot kering tanaman selada tidak dipengaruhi oleh varietas dan dipengaruhi oleh pupuk organik rumput laut, seperti dalam (Tabel 7) menunjukan R4 $(0,80 *)$ sangat berbeda nyata dengan $\mathrm{R} 0$ $(0,60), \mathrm{R} 1(0,63), \mathrm{R} 2(0,62), \mathrm{R} 3(0,70)$ dan tidak menunjukan adanya inteaksi pada bobot kering tanaman selada.

Tabel 7 Rata-rata bobot kering total tanaman selada

\begin{tabular}{|c|c|}
\hline & Bobot kering $(\mathrm{g})$ \\
\hline \multicolumn{2}{|l|}{ Varietas } \\
\hline V1 new grand rapid & 0,72 \\
\hline V2 new red fire & 0,69 \\
\hline \multicolumn{2}{|l|}{ Pupuk } \\
\hline R0 0 ton/ha & 0,60 \\
\hline R1 500 ton/ha & 0,63 \\
\hline R2 1000 ton/ha & 0,62 \\
\hline R3 1500 ton/ha & 0,70 \\
\hline R4 2000 ton/ha & 0,80 \\
\hline
\end{tabular}

Keterangan : Nilai rata-rata pada kolom yang sama diikuti tanda * berbeda nyata pada taraf $\mathrm{F} 0,05$ 


\section{Panjang Akar dan Panjang Tajuk}

Hasil sidik ragam (lampiran 6) menunjukan panjang akar tanaman selada dipengaruhi oleh varietas tetapi tidak dipengaruhi oleh perlakuan pupuk organik rumput laut dan tidak menunjukan adanya interaksi antara $\mathrm{V}$ dan $\mathrm{R}$, seperti dalam (Tabel 8) bahwa V1 $\left(9,58^{*}\right)$ berbeda nyata dengan V2 $(8,54)$.

Tabel 8 Rata-rata panjang akar tanaman selada

\begin{tabular}{lc}
\hline & Panjang akar $(\mathrm{cm})$ \\
\hline Varietas & \\
V1 new grand rapid & $9,58^{*}$ \\
V2 new red fire & 8,54 \\
\hline Pupuk & \\
R0 0 ton/ha & 10,47 \\
R1 500 ton/ha & 10,53 \\
R2 1000 ton/ha & 10,05 \\
R3 1500 ton/ha & 10,41 \\
R4 2000 ton/ha & 11,44 \\
\hline
\end{tabular}

Keterangan : Nilai rata-rata pada kolom yang sama diikuti tanda * berbeda nyata pada taraf $\mathrm{F} 0,05$

Hasil sidik ragam (Lampiran 7) menunjukan panjang tajuk tanaman selada tidak dipengaruhi oleh perlakuan pupuk organik rumput laut, tetapi dipengaruhi oleh vaietas, seperti dalam (Tabel 9) menunjukan bahwa V1 $\left(13,04^{*}\right)$ berbeda nyata dengan V2 $(11,95)$ dan tidak menunjukan adanya interaksi antara V x R

Tabel 9 Rata-rata panjang tajuk tanaman selada

\begin{tabular}{lc}
\hline & Panjang tajuk $(\mathrm{cm})$ \\
\hline \multicolumn{1}{c}{ Varietas } \\
V1 new grand rapid & $13,04^{*}$ \\
V2 new red fire & 11,95 \\
\hline \multicolumn{2}{c}{ Pupuk } \\
\hline R0 0 ton/ha \\
R1 500 ton/ha \\
R2 1000 ton/ha & 12,34 \\
R3 1500 ton/ha & 12,44 \\
R4 2000 ton/ha & 11,94 \\
\hline
\end{tabular}

Keterangan : Nilai rata-rata pada kolom yang sama diikuti tanda * berbeda nyata pada taraf F 0,05

\section{Bobot Akar dan Bobot Tajuk}

Hasil sidik ragam (Lampiran 8) berat akar tanaman selada tidak dipengaruhi oleh pupuk organik rumput laut, tetapi dipengaruhi oleh varietas, seperti dalam (Tabel 10) menunjukan bahwa V1 $(3,49 *)$ berbeda nyata dengan V2 $(1,96)$ dan tidak menunjukan adanya intaraksi antara $\mathrm{V} x \mathrm{R}$.

Tabel 10 Rata-rata bobot akar tanaman selada

\begin{tabular}{lc}
\hline & Bobot akar $(\mathrm{g})$ \\
\hline \multicolumn{2}{c}{ Varietas } \\
V1 new grand rapid & $3,49 *$ \\
V2 new red fire & 1,96 \\
\hline \multicolumn{2}{c}{ Pupuk } \\
R0 0 ton/ha \\
R1 500 ton/ha \\
R2 1000 ton/ha \\
R3 1500 ton/ha \\
R4 2000 ton/ha \\
\hline Keterangan : Nilai rata-rata pada kolom yang sama \\
diikuti tanda * berbeda nyata pada taraf F \\
0,05
\end{tabular}

Hasil sidik ragam (Lampiran 9) berat tajuk tanaman selada dipengaruhi oleh pupuk organik rumput laut, tetapi dipengaruhi oleh varietas, seperti dalam (Tabel 11) menunjukan bahwa V1 $(12,49 *)$ berbeda nyata dengan V2 $(6,68)$.

Tabel 11 Rata-rata bobot tajuk tanaman selada

\begin{tabular}{lc}
\hline & Bobot tajuk $(\mathrm{g})$ \\
\hline \multicolumn{1}{c}{ Varietas } \\
V1 new grand rapid & $12,49 *$ \\
V2 new red fire & 6,68 \\
\hline \multicolumn{2}{c}{ Pupuk } \\
R0 0 ton/ha \\
R1 500 ton/ha \\
R2 1000 ton/ha \\
R3 1500 ton/ha & 10,50 \\
R4 2000 ton/ha & 11,89 \\
\hline Keterangan : Nilai rata-rata pada kolom yang sama \\
diikuti tanda * berbeda nyata pada taraf F 0,05
\end{tabular}


Hasil uji lanjut (Tabel 11) berat tajuk tanaman selada menunukan adanya interaksi. perlakuan R4V1 (21,67 c) sangat berbeda nyata dengan perlakuan R0V1 (9,22 ab), R1V1 (11,56 ab), R2V (16,67 ab) dan R3V1 (13,33 b), sedangkan perlakuan R3V2 (7,78 ab) tidak berbeda nyata dengan perlakuan R0V2 (7,78 ab) tetapi berbeda nyata dengan perlakuan R1V2 (6,44 ab), R2V2 (6,94 ab) dan R4V2 (4,44 a).

Tabel 12 Hasil uji lanjut bobot tajuk tanaman selada DMRT 5\%

\begin{tabular}{lrr}
\hline \multirow{2}{*}{ Perlakuan } & \multicolumn{2}{c}{ Bobot tajuk } \\
\cline { 2 - 3 } & $9,22 \mathrm{ab}$ & $\mathrm{V} 2$ \\
\hline R0 0 ton/ha & $11,56 \mathrm{ab}$ & $6,78 \mathrm{ab}$ \\
R1 500 ton/ha & $6,67 \mathrm{ab}$ & $6,44 \mathrm{ab}$ \\
R2 1000 ton/ha & $13,33 \mathrm{~b}$ & $7,78 \mathrm{ab}$ \\
R3 1500 ton/ha & $21,67 \mathrm{c}$ & $4,44 \mathrm{a}$ \\
R4 2000 ton/ha &
\end{tabular}

Keterangan : Nilai rata-rata pada kolom yang sama diikuti huruf yang sama tidak berbeda nyata menurut uji DMRT taraf 5\%

\section{Padatan Terlarut Total (PTT)}

Hasil sidik ragam (Lampiran 10) padatan terlarut total tanaman selada tidak dipengaruhi oleh pupuk organik rumput laut, varietas dan tidak ada interaksi keduanya (Tabel 13)

Tabel 13 Rata-rata padatan terlarut total (PTT) tanaman selada

\begin{tabular}{|c|c|}
\hline & PTT (brix \%) \\
\hline \multicolumn{2}{|l|}{ Varietas } \\
\hline V1 new grand rapid & 4,47 \\
\hline $\mathrm{V} 2$ new red fire & 4,13 \\
\hline \multicolumn{2}{|l|}{ Pupuk } \\
\hline R0 0 ton/ha & 4,83 \\
\hline R1 500 ton/ha & 4,00 \\
\hline R2 1000 ton/ha & 4,17 \\
\hline R3 1500 ton/ha & 4,00 \\
\hline R4 2000 ton/ha & 4,50 \\
\hline
\end{tabular}

Keterangan : Nilai rata-rata pada kolom tidak berbeda nyata pada taraf $\mathrm{F} 0,05$

\section{Keadaan Tanah}

Berdasarkan Balai Penelitian Tanah (dalam Nawawi 2013), tanah yang digunakan dalam penelitian ini memilki kandungan bahan $\mathrm{C}$ organik 1,78\% (Walkey Black), $\mathrm{N}$ organik o,14\% (Kjeldahl), $\mathrm{C} / \mathrm{N}$ rasio $13, \mathrm{pH}$ 6,0 (H2O) dan pH 5,1 (KCL), P2O5 105 ppm (Olsen,) K2O 631 ppm (Morgan) dan KTK 25,47. Berdasarkan kriteria kesuburan tanah dari Balai Penelitian Tanah dalam Hardjowigeno (2002), hasil analisis tanah top soil kebun percobaan Agroteknologi Universitas Djuanda memilki kandungan Corganik dan $\mathrm{N}$-organik rendah, $\mathrm{C} / \mathrm{N}$ rasio sedang, P2O5 sangat tinggi, K2O sedang, KTK sedang dan $\mathrm{pH}$ tanah agak masam.

Pengaruh interaksi pemberian pupuk organik rumput terhadap varietas

Interaksi perlakuan pupuk organik rumput laut pada varietas hanya terdapat pada bobot basah total perlakuan R4V1 (25,56 c) menghasilkan bobot basah total lebih besar dibandingkan dengan perlakuan lainnya dan pada bobot tajuk perlakuan R4V1 (21,67 c) menghasilkan bobot tajuk lebih besar dibandingkan dengan perlakuan lainnya. Menurut Wibisono dan Basri (1993) bahwa tanaman dapat tumbuh dan berproduksi dengan optimal apabila unsur hara yang diperlukan mencukupi. Unsur hara sangat diperlukan oleh tanaman untuk membentuk suatu senyawa yang diperlukan untuk pertumbuhan tanaman melalui pembelahan dan pembesaran selada.

\section{Pengaruh pupuk organik rumput laut}

Hasil penelitian menunjukan bahwa Perlakuan pupuk organik rumput laut tidak berpengaruh nyata terhadap hampir semua peubah yang diamati, kecuali tinggi tanaman (4 MST dan 5 MST), jumlah daun (4 MST dan 5 MST), luas daun dan bobot kering. Hal tersebut diduga pemberian dosis pupuk organik rumput laut belum maksimal. Rachmat (2010) memaparkan berdasarkan hasil uji antara pupuk rumput laut padat, cair maupun campuran keduanya dengan urea, diketahui kondisi tanaman yang menggunakan pupuk rumput laut lebih subur. Tanaman yang di beri pupuk organik rumput laut batang lebih besar dan tegak, urat daun terasa kasar, batang tidak mudah patah dan daun berwarna hijau serta tidak sobek. 
Perlakuan pupuk organik rumput laut dosis 2 rekomdasi adalah nyata menghasilkan tinggi tanaman, jumlah daun, bobot basah, panjang akar, panjang tajuk dan bobot tajuk tanaman tang lebih tinggi dibandingkan dengan perlakuan lainnya. Menurut Fardiaz (1992) padatan terlarut total menunjukan partikel padat yang terdapat di dalam air hasil ekstraksi hasil tanaman. Padatan ini terdiri dari senyawa anorganik dan organik yang laut dalam air, mineral dan garam-garamnya. Padatan terlarut total (PTT) tanaman selada tidak berbeda nyata baik pada varietas, pupuk organik rumput laut dan tidak ada interaksi keduanya.

\section{KESIMPULAN}

\section{Kesimpulan}

1. Perlakuan pupuk organik rumput laut tidak berpengaruh nyata terhadap hampir semua peubah yang diamati, kecuali tinggi tanaman (4 MST dan 5 MST), jumlah daun (4 MST dan 5 MST), luas daun dan bobot kering semuanya berbeda nyata.

2. Perlakuan R4 (2000 ton/ha) lebih berbeda nyata dengan R0 (0 ton/ha) dilihat dari semua peubah yang diamati.

3. Interaksi antara perlakuan pupuk organik rumput laut dengan varietas tidak menunjukan adanya interaksi yang nyata terhadap hampir semua peubah yang diamati, kecuali bobot basah dan panjang tajuk.

4. Perlakuan pupuk organik rumput laut terhadap V1 (var. new grand rapid) lebih baik dibandingkan dengan perlakuan pupuk organik rumput laut terhadap V2 (var. New red fire).

\section{DAFTAR PUSTAKA}

Basmal J Ir. M,Sc. 2012. Rumput Laut Bahan Pupuk Organik Prosfektif. Badan Penelitian Kelautan dan Perikanan. Departemen Kelautan dan Perikanan. Jakarta.

Balai Pengkajian Teknologi Pertanian (BPTP Jambi). 2009. Budidaya Selada Semi Organik. Jambi: Departemen Pertanian

Cahyono B, 2010. Teknik Budidaya dan Analisis Usaha Tani Selada. Semarang : $\mathrm{Cv}$ Aneka Ilmu

Hardjowigeno. 2002. Ilmu Tanah. Jakarta: Akademi Pressindo.

Nanang A. 203. Kekurangan dan Keunggulan Pupuk Organik dan Anorganik. http://www. kekurangan dan keungguan pupuk organik dan anorganik.htm.

Nawawi AHS. 2013. Pertumbuhan dan produksi sawi manis (Brassica junces L.) pada berbegai konsentrasi urine sapi dan pupuk N, P dan K. [Skripsi]. Bogor: Universitas Djuanda.

Notohadinegoro, T. 2006. Faktor Tanah dalam Pengembangan Hotikultura. Ilmu tanah Universitas Gajah Mada.

Rachmat R. 2010. Pupuk ramah lingkungan dari pupuk rumput laut. Jakarta. Kementrian Kelautan dan Perikanan Republik Indonesia.

Rukmana R. 2008. Kubis Bunga \& Brocoli. Yogyakarta. Penerbit Kanisius.

Wibisono A dan Basri M. 1993. Pemanfatan Limbah Organik Untuk Kompos. Jakarta. Penebar Swadaya

Wicaksono,A. 2008. Penyimpanan Bahan Makanan Serta Kerusakan Selada. Skripsi . Fakultas Politeknik Kesehatan. Yogyakarta. 